\title{
Tourism in retrospect of COVID-19 on global perspective using analytical hierarchy process
}

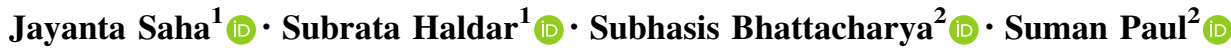

Received: 8 February 2021/Revised: 14 May 2021 / Accepted: 18 May 2021 / Published online: 2 June 2021

(C) Korean Spatial Information Society 2021

\begin{abstract}
Covid-19 pandemic has brought remarkable shocks over tourism globally. In case of tourism such experience of epidemic is quite new in terms of time gestation. Even world agencies cannot estimate the amount of loss and fails to predict the full pace running stage of the sector. The study tries to estimate the impact of pandemic over the tourism. Rather than these, the main aspect of the study is to formulate a rank resulted by tourism impact of the studied countries over its economics considering the variables like GDP share of tourism and number of tourist arrivals (2017, 2018 and 2019), tourism dependency rate, tourism competitive index, jobs directly depends on tourism and contribution of tourism in terms of international receipts. The study uses Analytical Hierarchical Process to estimate the impact of Covid-19 over tourism. Results shows the countries with higher dependencies over tourism severely affected and those results are in linearity.
\end{abstract}

Keywords Tourism · Covid-19 · Impact · Analytical hierarchical process

Suman Paul

suman.krish.2007@gmail.com

Jayanta Saha

jayantasaha.001@ rediffmail.com

Subrata Haldar

s.haldar90@gmail.com

Subhasis Bhattacharya

suva69eco@gmail.com

1 Dept. of Geography, Sidho Kanho Birsha University, Purulia, West Bengal 723104, India

2 Dept. of Economics, Sidho Kanho Birsha University, Purulia, West Bengal 723104, India

\section{Introduction}

During mid of December-2019, from Wuhan city of China, the virus initially outbreaks, and spread over different nations mainly through airways [1]. World Health Organization (WHO) identified the fact is that such Covid-19 virus spread over 206 nations and their territories severely [2]. Studies before Covid-19 already identified that infectious disease outbreak are the major upshots over tourism industries over the world [3]. The Covid-19 situations leads to two fold loss, one in terms of human life and another in terms of shut down of economic activities. Most of nations provide support in terms of benefit transfer, which is observed within the stringency factors identified by data capturing centre [4]. International organisations already predicted economic slowdown, which may be, prolonged towards the first half of 2021 [5]. The prolonged effect of Covid-19 is disrespects different functioning wings of various economics of the world. Normal life as well as earning competence of especially marginal people tremendously affected [6].

The countries, which are, depending mainly from medium and small-scale industries, as well as service sector, are the major shock absorber. Tourism industry is one example of such mostly affected sector. Airlines have some significant role in amplifying and accelerating the wide spread disease like influenza and coronavirus [7]. Spreading of Covid-19 virus mainly through airline passengers become famous and the movements is restricted guided by the policies of the states. Hence, the tourism, which mainly depends on movements, receives the very initial income squeezing shock [1]. Like airways cruise service is also affected by the pandemic and the large cruise business houses of Norwegian and Caribbean Island are suffering huge loss over the pandemic period [8]. 
Studies try to correlate the incidence of Covid-19 pandemic (regarded as SARS-CoV-2 later) over the globe promoted by tourism industry [9]. During the initiation of the disease common outcomes are airlines and cruise based travel restrictions, border closure, internal lockdown etc. to curb the spread of the virus [7].

Studies also reveal that growth of urban centres and malicious policy of demographic concentration towards urban centres gets smaller attention rather than shut down of tourism activity [10]. Especially developing countries spread their tourism activity without developing proper infrastructure like healthcare facilities at the tourist destinations. But there are several examples show tourism promotes development contemplating both the social costs and social benefits dimensions of it $[11,12]$. It is also inevitable that the social cost of tourism becomes heavy during such pandemic environment, but we have to remind the facts of livelihood of those people solely dependent on such industry [13, 14]. The major insertion over tourism created by the pandemic becomes easier because today we are leaving in such a world with fast growing mobile world population, urban concentrated demographic development, increase in industrial food production with a solid global supply chain, and development of transport networks, and all these acts as creative vectors to spread the disease $[15,16]$.

Integration of Analytical Hierarchy Process (AHP), a method for multi rules analysis with GIS in land rationality examinations is appropriate for many plans [17-19] since AHP works with the assignment of loads to factors influencing land suitability and has a high limit with regards to mix of heterogeneous data [20]. The strategy, which empowers evaluation of cooperative choices with a particular precise and logical approach, is utilized to pick the best alternative among the decided choices for a particular purpose considering various rules [21]. AHP gives a demonstrated, powerful intends to manage complex dynamic and can help with distinguishing and gauging standards, investigating the information gathered and speeding up the dynamic interaction. The positioning interaction will require a significant long time if physically dissected. So to deal with information rapidly requires a positioning technique that is AHP. AHP will be utilized during the time spent positioning the travel industry in East Asia to decide the notoriety of existing the travel industry.

Present study tries to capture the loss (not only in monetary terms) of the tourism sector over some countries, which has very proactive income source from such industries. Before doing that, studies tries to make deeper understanding about tourism dependencies of the different regions over the globe. The present study tries to construct an impact measurement effect of tourism over the economy considering the variables like Gross Domestic Production
(GDP) share of tourism and number of tourist arrivals over 2017, 2018 and 2019, tourism dependency rate, tourism competitive index, jobs directly depends on tourism and contribution of tourism in terms of international receipts. The study uses AHP to estimate the impact of Covid-19 over tourism economy.

\section{Background}

Several studies try to capture the effects of different shocks on the tourism industry [14, 22-27]. The backdrop of such study identified that demand for tourism during such Covid-19 episode cleanly sinking and an acute level of uncertainties faced by the actors related with such sector [28]. People with only earning source from this sector becomes critically exposed by the crisis of Covid-19 [29]. Studies also reveal that the way of amplification of tourism industry from such natural or pandemic crisis paid less attention in compare to other [30]. But these should be viewed as other interconnected business system [31].

During pre Covid-19 scenario, the tourism sector hindered by different shocks closely found visible from 9 to 11 (2001) fall down of World Trade Centre, then during 2005 due to outbreak of Severe Acute Respiratory Syndrome (SARS), then the global economic crisis of 2008-09 and lastly by the outbreak of Middle East Respiratory Syndrome (MERS) during 2015. But the effect of such crisis over the global tourism is not very significant with respect to wide spread Covid-19. SARS (2003) reduces the global arrivals at a rate of $-0.4 \%$ and the global economic crisis of 2008-09 reduces it by $4.0 \%$ [6, 32]. Such results may generate some ideas that sector like tourism can recover the after shock situation after any pandemic. But the situation like post-Covid-19 has something different kind of shading over the tourism sector and it is also further scope to estimate that after how much time such sector becomes resilient to bypass the memories of loss incur during Covid-19 retro. The shock of Covid-19 is so deep that the British Airlines (FlyBe) declared bankruptcy (on 05.03.2020), and followed by others like Scandinavian Airlines (on 17.03.2020), Singapore Airlines (27.03.2020) etc. demanded for the state aid amounting US\$ 10 billion [33].

Due to stringency measure adopted by the governments to restrict the movement during such pandemic, hotels and restaurants are going for shut down for uncertain periods and the supply chain industries of tourism like caterings and laundry services are profoundly affected. The United Nations World Tourism Organisations [34] forecasted during the starting of March, 2020, that due to Covid-19, world wide number of tourist arrivals will be reduced by 1-3\% (in compare to 2019) during 2020 and that leads to 
reduction in growth of the tourism industry by $3-4 \%$ [35]. But at the end of March 2020, it again predicts that the loss of tourist arrivals may be lead to 20-30\% [36]. Such foremost amendment can help us to fathom the depth of crisis over tourism sector marked by Covid-19 pandemic. This study enlightened by the observed facts and literatures and tries to estimate the impact of Covid-19 on 50 countries over the globe. It is concerned about the authenticity of the data set and the data sets are mainly collected from the prominent sources like World Bank, UNWTO World Travel and Tourism Council etc.

\section{Materials \& methods}

\subsection{Tourism data acquisition}

As the research been falls within the Global tourism perspective, data support from United Nations Wold Tourism Organisation (UNWTO) is very essential. For our analysis, data set from 'World Tourism Barometer' has been accessed and Global perspective dataset during Q1 and Q2 (January-June) of 2020 have been taken into consideration. Tourism arrival during 2017-2019 has been accessed with the monthly and quarterly data series. Other tourism related variable like, GDP share from tourism sector, jobs (formal and non-formal) under tourism sector and dependency on tourism has been accessed from World Bank [37] repository for the countries ranked $1-50$ in respect of international tourist arrival in 2019 (see Fig. 1). For addressing the nature of travel and tourism competitiveness, we have gone through 'Insight Report' from world economic forum. To assess the nature of tourism impact due to SARS-Cov-2 pandemic, researchers have used several materials, which have been stated in the Table 1 .

\subsection{Selection of indicators}

During 2018-19, tourism industry played a major role of Global GDP, which is nearly $10.4 \%$, and generate nearly same share of employment. Hence the criterion selection is very important to understand the overall impact of tourism or economy. GDP share from tourism sector suggest a growth of 0.5 per cent in per capita income with $1 \%$ GDP increase. This GDP increase not only increases the per capita income but also encourage jobs in tourism sector. In this perspective the foreign tourist's arrival and receipts from tourism sector grow which make a country much more dependent on tourism economy. Tourism flow in different countries during ongoing pandemic hampered a lot which can directly make country's GDP at stake. In this setting five indicators have been taken into consideration to assess the impact of tourism on economy for the first 50 countries of tourist arrival during 2019.

\subsubsection{GDP share in country's income}

GDP share is one of the important indicators of the economic strength of global GDP share has been accounted in 2019 from travel and tourism industry. Despite the slow opening of tourist destinations during May-June 2020 due to ongoing pandemic (Covid-19), massive loss of 460million US\$ has been estimated for the first half of the year.

\subsubsection{Jobs in tourism Sector}

Travel and tourism industry offers a lot of employment in direct and indirect way in diverse manner. Nearly 300 million population in the world are engaged with this sectors and 505 of them under the age of 25 years. This sector promotes younger age groups where global average for women found dominating and within the age groups of 20-30 years. China and India contributed higher employment to other parts of the world with 29 and 27.5 million population. Though, the European countries have much higher tourist arrival, only Germany sharing over three million staff in hotel and tourism industry. According to World Travel and Tourism Council [38], near about 50 million potential jobs loss will be took place due to this ongoing pandemic which has been hit hard global economy.

\subsubsection{Arrival of international tourist}

International tourist's arrival is the prime indicators for economic sustainability as the share and growth during last 5 years it is constantly increasing. During SARS-Cov-2 (Covid-19) the worldwide travel has make this sector of economy in drastic fall and during first half of the year international tourist arrival (overnight visitors) has declined nearly $65 \%$ over the same period for last year.

\subsubsection{Tourism receipts}

During 2018, Global tourism receipt has been found 1.649 trillion US $\$$ at current price out of which USA has been estimated as 256.15 billion US\$. Countries in Europe have been found as most earning to global share while Thailand has a earning of 65.24 billion US\$ during 2018 [39]. UNDP has suggested developing tourism industry as green economy in SDG for support the local economy and reducing the poverty. Pandemic in this year has made a stand still market for USA and China where as some improvement has been found for Germany, France on the latter half (from May-June onwards) of 2020. 


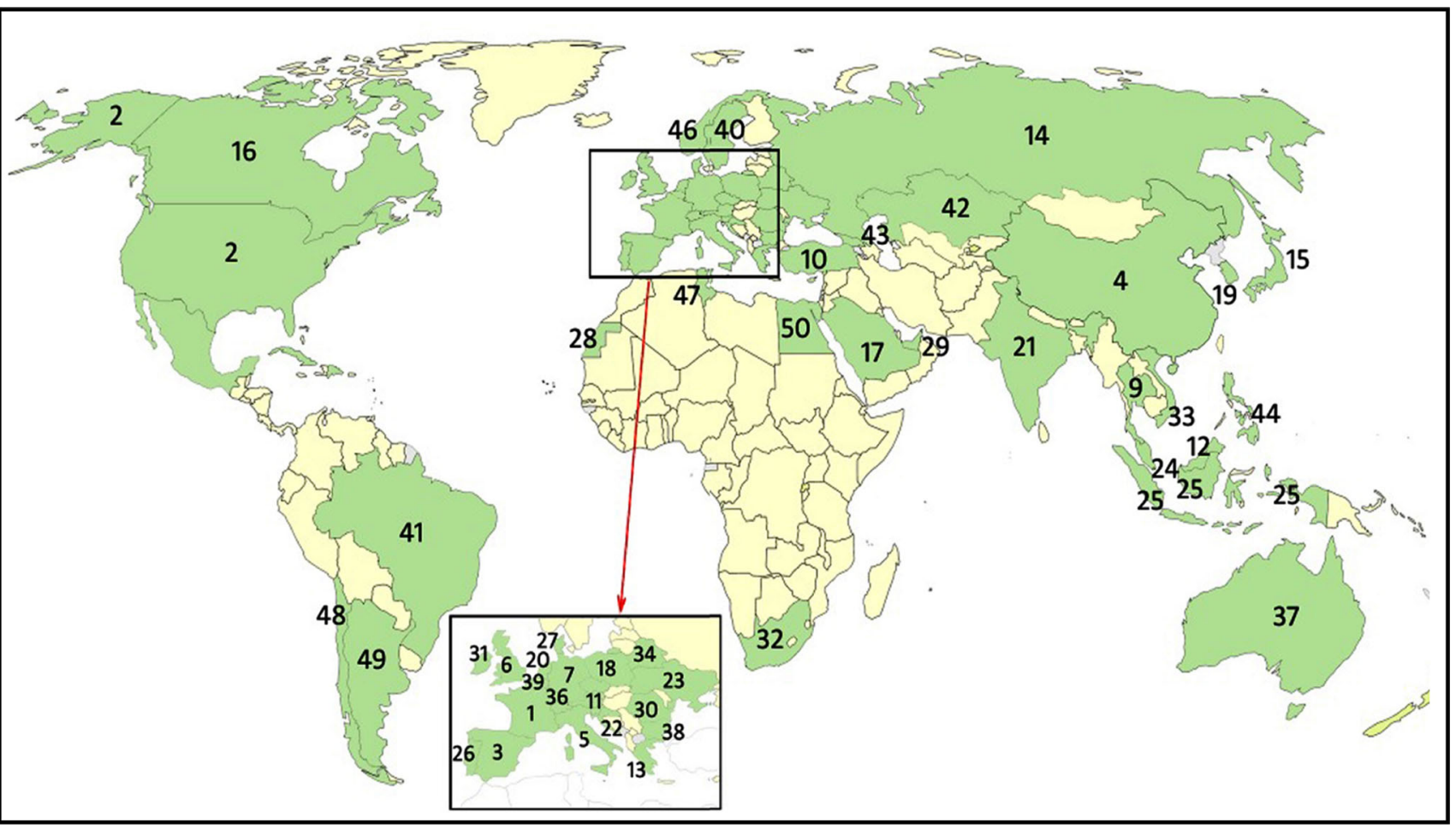

Fig. 1 Selected first ranked 50 countries depending on 2019 international tourist arrival N.B. Rank of the countries: 1. France, 2. USA, 3. Spain, 4. China, 5. Italy, 6. United Kingdom, 7. Germany, 8. Mexico, 9. Thailand, 10. Turkey, 11. Austria, 12. Malaysia, 13. Greece, 14. Russia, 15. Japan, 16. Canada, 17. Saudi Arabia, 18. Poland, 19. South Korea, 20. Netherlands, 21. India, 22. Croatia, 23.
Ukraine, 24. Singapore, 25. Indonesia, 26. Portugal, 27. Denmark, 28. Morocco, 29. UAE, 30. Romania, 31. Ireland, 32. South Africa, 33. Vietnam, 34. Belarus, 35. Czech Republic, 36. Switzerland, 37. Australia, 38. Bulgaria, 39. Belgium, 40. Sweden, 41. Brazil, 42. Kazakhstan, 43. Georgia, 44. Philippines, 45. Dominican Republic, 46. Norway, 47. Tunisia, 48. Chile, 49. Argentina and 50. Egypt
Table 1 Materials and its sources

\begin{tabular}{ll}
\hline Indicators & Source of the materials \\
\hline GDP share in country's income & $\mathrm{https} / / \mathrm{knoema} \cdot c o m / \mathrm{data} /$ \\
Jobs in tourism sector & $\mathrm{https} / / \mathrm{knoema} . c o m / \mathrm{data} /$ \\
Arrival of international tourist & $\mathrm{https} / /$ ourworldindata.org/ \\
Tourism receipts & $\mathrm{https} / / \mathrm{knoema} . c o m / \mathrm{atlas} / \mathrm{maps} / \mathrm{Tourism}-\mathrm{receipts}$ \\
Tourism dependency index & $\mathrm{https} / / \mathrm{knoema} \cdot \mathrm{com} / \mathrm{data} /$ \\
\hline
\end{tabular}

\subsubsection{Tourism dependency index}

Tourism Dependency index has been developed by world bank to stand the economic dependency of a country on tourism and this index has been developed with the sub indicators like, (i) Total expert received, (ii) output share for real GDP, (iii) employment share. This index varies from 0 to 100 , where 100 representing the total dependency on sector.

\subsection{Weighting, normalisation and mapping}

Analytical Hierarchical Process (AHP) has been applied on 5 indicators, which have been developed by Satty [21] to facilitate priority setting, and decision-making. AHP now broadly applied in social science research and specifically in hazard and risk analysis. For assessing the multi-hazards risk zone, several hazards have been taken into consideration and giving weightage according to researchers experience and based on local people's perception. In this technique a pairwise matrix has been developed among the set of scale of choices (see Table 2) on the given alternatives as a first step. Pairwise matrix has been measured in nine point judiciary scale as; $1=$ equal, $3=$ moderate, $5=$ strong, $7=$ very strong and $9=$ extreme strong relation. Intermediate values are lies as 2, 4, 6 and 8. The reversal scale has been valued from 1 to $1 / 9$. AHP methods also deliver to judge the nature of consistency of preferences given by the report using consistency ratio when the 
Table 2 AHP pairwise matrix, weightage and consistency measurement of indicators for country-wise Tourism Impact on Economy due to COVID-19

\begin{tabular}{|c|c|c|c|c|c|c|c|c|c|}
\hline Indicators & $\begin{array}{l}\text { GDP share in } \\
\text { country's Income }\end{array}$ & $\begin{array}{l}\text { Jobs in } \\
\text { tourism } \\
\text { Sector }\end{array}$ & $\begin{array}{l}\text { Arrival of } \\
\text { international } \\
\text { touris }\end{array}$ & $\begin{array}{l}\text { Tourism } \\
\text { receipts }\end{array}$ & $\begin{array}{l}\text { Tourism } \\
\text { dependency } \\
\text { index }\end{array}$ & $\mathrm{Cp}$ & $\lambda \max$ & $\mathrm{CI}$ & $\mathrm{CR}$ \\
\hline $\begin{array}{l}\text { GDP share in } \\
\text { country's income }\end{array}$ & 1.00 & 7.00 & 5.00 & 5.00 & 7.00 & 0.42 & \multirow[t]{6}{*}{5.584} & 0.117 & \multirow[t]{6}{*}{0.089} \\
\hline $\begin{array}{l}\text { Jobs in tourism } \\
\text { sector }\end{array}$ & 0.14 & 1.00 & 7.00 & 5.00 & 9.00 & 0.27 & & & \\
\hline $\begin{array}{l}\text { Arrival of } \\
\text { international } \\
\text { tourist }\end{array}$ & 0.20 & 0.14 & 1.00 & 7.00 & 5.00 & 0.21 & & & \\
\hline Tourism receipts & 0.20 & 0.20 & 0.14 & 1.00 & 9.00 & 0.07 & & & \\
\hline $\begin{array}{l}\text { Tourism } \\
\text { dependency index }\end{array}$ & 0.14 & 0.11 & 0.20 & 0.11 & 1.00 & 0.03 & & & \\
\hline Sum & 1.68 & 8.45 & 13.34 & 18.11 & 31.00 & 1.00 & & & \\
\hline
\end{tabular}

value has $0.10(\mathrm{CR}=>0.10)$. The consistency ratio is defined as:

$\mathrm{CR}=\mathrm{CI} / \mathrm{RI}$

where, $\mathrm{CR}$ is consistency ratio, $\mathrm{RI}$ represent random number (table-) and CI represent consistency ratio is expressed by
$\mathrm{CI}=(\lambda \max -\mathrm{n}) /(\mathrm{n}-1)$

For the present study, consistency ratio has been found as 0.116 , consistency index as 0.094 and the value of random number for $\mathrm{n}=6$ when $\lambda$ max has been determined 6.584 (see Table 2).

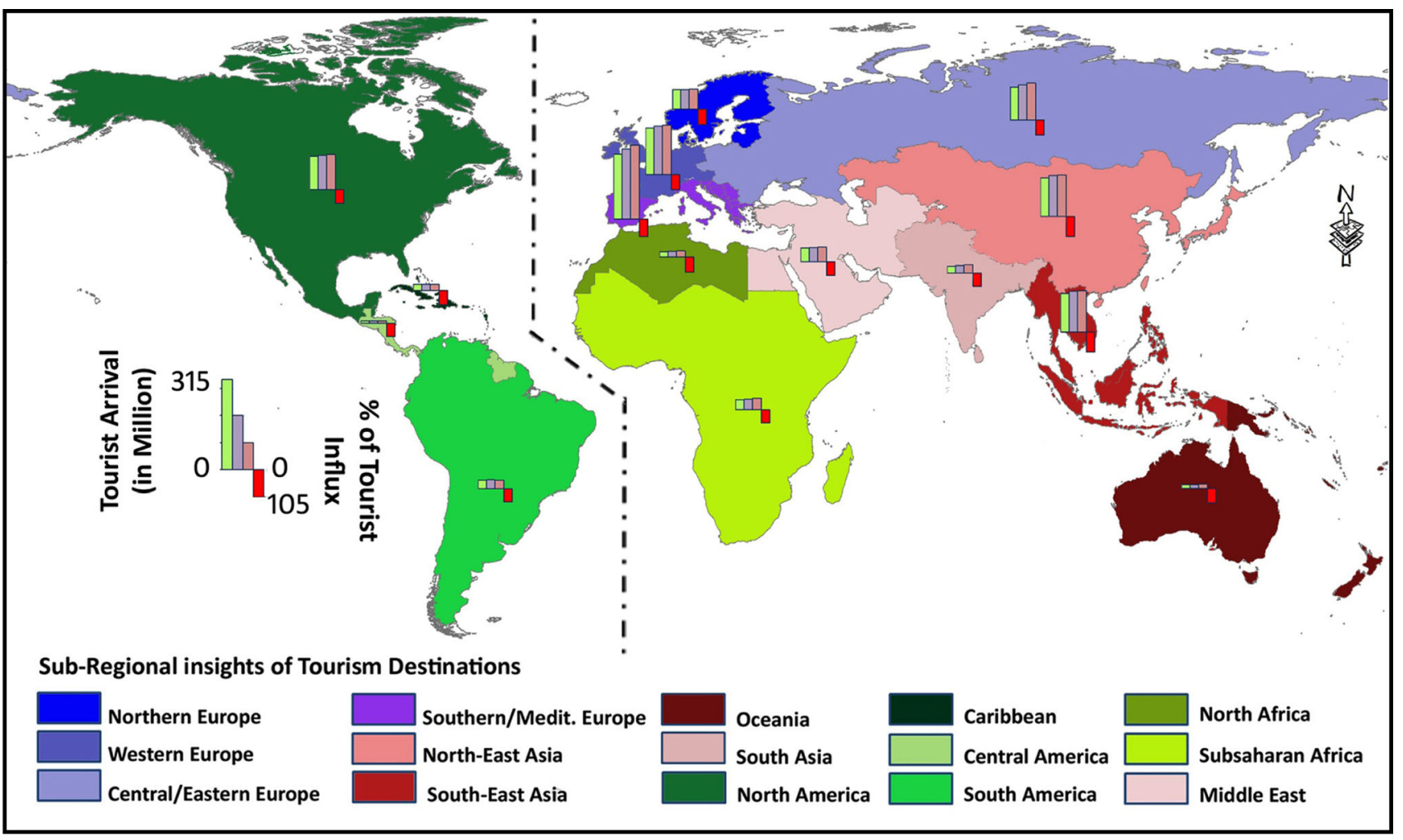

Fig. 2 Tourism growth pattern with \% of change over same period of the previous year (Q1 \& Q2 of 2020) and share of tourist influx-a subregional variation 
Table 3 International tourist arrivals by sub-region and \% of change over same period of the previous year (2020)

\begin{tabular}{|c|c|c|c|c|c|c|c|c|c|c|}
\hline \multirow[t]{2}{*}{ Tourism sub-regions } & \multicolumn{3}{|c|}{$\begin{array}{l}\text { International tourist arrivals by sub-region } \\
\text { (in million) }\end{array}$} & \multirow[t]{2}{*}{ YTD } & \multicolumn{6}{|c|}{$\%$ of change over same period of the previous year (2020) } \\
\hline & 2017 & 2018 & $2019 *$ & & Jan & Feb & Mar & Apr & May & Jun \\
\hline Northern Europe & 81.01 & 81.04 & 82.62 & -64.21 & 5.42 & 4.32 & -56.63 & -96.71 & -96.63 & -94.27 \\
\hline Western Europe & 192.72 & 200.21 & 204.74 & -62.72 & 8.21 & 6.21 & -64.42 & -98.12 & -96.61 & -82.45 \\
\hline Central/Eastern Eur & 135.05 & 146.22 & 152.92 & -61.94 & 1.02 & -2.11 & -45.61 & -97.31 & -972 & -88.74 \\
\hline Southern/Medit. Eur & 267.91 & 288.64 & 304.11 & -72.42 & 4.81 & 1.31 & -69.54 & -97.44 & -95.74 & -93.87 \\
\hline North- East Asia & 159.54 & 169.21 & 170.62 & -82.53 & -19.41 & -80.21 & -94.43 & -99.33 & -98.92 & -98.52 \\
\hline South- East Asia & 120.62 & 128.61 & 136.81 & -64.44 & 6.92 & -35.91 & -72.07 & -98.21 & -98.28 & -98.41 \\
\hline Oceania & 16.61 & 17.04 & 17.52 & -58.22 & 5.51 & -20.22 & -60.01 & -97.84 & -99.23 & -99.21 \\
\hline South Asia & 27.52 & 32.81 & 35.21 & -55.02 & 6.94 & -4.11 & -70.21 & -97.32 & -97.74 & -99.62 \\
\hline North America & 137.48 & 142.23 & 146.42 & -55.51 & 3.72 & 4.14 & -45.12 & -91.21 & -90.12 & -89.53 \\
\hline Caribbean & 25.82 & 25.78 & 26.82 & -57.73 & -2.21 & 0.31 & -57.22 & -97.62 & -99.35 & -98.68 \\
\hline Central America & 11.11 & 10.79 & 10.94 & -54.74 & -2.75 & 6.61 & -55.04 & -964 & -99.14 & -99.17 \\
\hline South America & 36.65 & 37.11 & 35.31 & -52.32 & -5.31 & 1.22 & -56.45 & -98.88 & -99.68 & -99.65 \\
\hline North Africa & 21.73 & 24.13 & 25.62 & -62.45 & 5.33 & 4.81 & -56.64 & -97.29 & -99.47 & -98.23 \\
\hline Sub- Saharan Africa & 41.71 & 44.62 & 46.82 & -54.12 & 1.04 & -0.21 & -36.32 & -99.68 & -99.52 & -99.55 \\
\hline Middle East & 57.66 & 60.14 & 61.42 & -56.91 & 5.32 & -24.72 & -44.62 & -94.12 & -94.31 & -93.68 \\
\hline
\end{tabular}

YTD Year-to-date refers to the change in the months with data available, compared to the same period of the previous year. The Sub-regional totals are approximations for the whole Sub-region based on trends in countries for which data is available

*Provisional Data

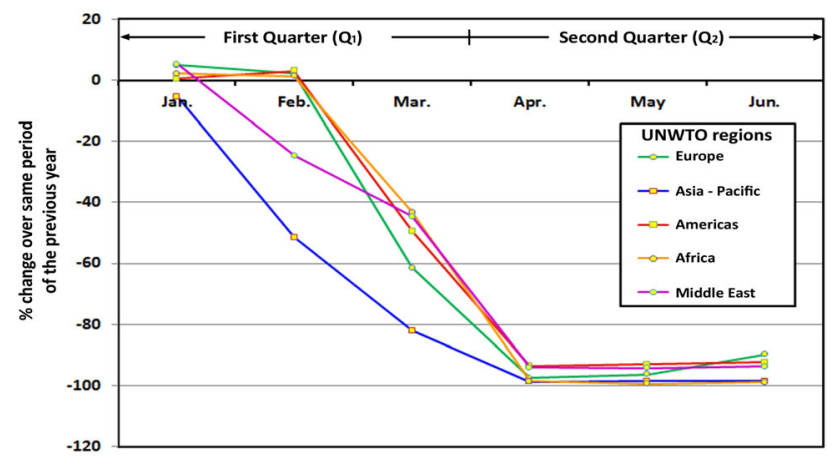

Fig. 3 Tourism declining pattern (in \%) over same period of the previous year (Q1 \& Q2 of 2020) in UNWTO tourism regions

In order to place all the indicators in same format, the linear pattern of scale transformation method has been applied using equation- 1 . The normalize values have range between 0 and 1 .

$\mathrm{T}=\mathrm{X}$ value $-\min / \max -\min$

where, $\mathrm{T}$ is the normalise value of the indicators $\mathrm{X}$ value is the actual value of the individual country and min and max representing the minimum and maximum values associated with the each indicators. After having the normalization value, the weightage value has been multiplied with the indicators normalised value and summed up to develop an index termed as 'Tourism Impact on Economy; (TIE) which has been shown below:

$$
\begin{aligned}
\mathrm{TIE}= & w_{\mathrm{GDP}} . \mathrm{GDP} i+w_{\mathrm{J}} . \mathrm{J} i+w_{\mathrm{TA}} . \mathrm{TA} i+w_{\mathrm{GDP}} \cdot \mathrm{GDP} i \\
& +w_{\mathrm{TR}} . \mathrm{TR} i+w_{\mathrm{TD}} . \mathrm{TD} i
\end{aligned}
$$

To visualise the results in spatial dimension, spatial analytical tool in ARC GIS 10.3 software has been used and the resulted map has been classified in very high to very low index for each of the criteria.

\section{Results and discussion}

The results and analysis has been done in two perspectives-(a) Regional insights of tourism and its situation due to ongoing pandemic and (b) Assessment of impact of SARS-CoV-2 on tourism industry of first 50 countries in respect of international tourist arrival in 2018-19.

\subsection{Regional insights of tourism}

Present IATA (International Air Transport Association) data indicates the demand of international flight passenger has dropped nearly 67\% during first two quarters (Q1 \& Q2) in case of year-on-year (y-o-y) is concern. Opening of 


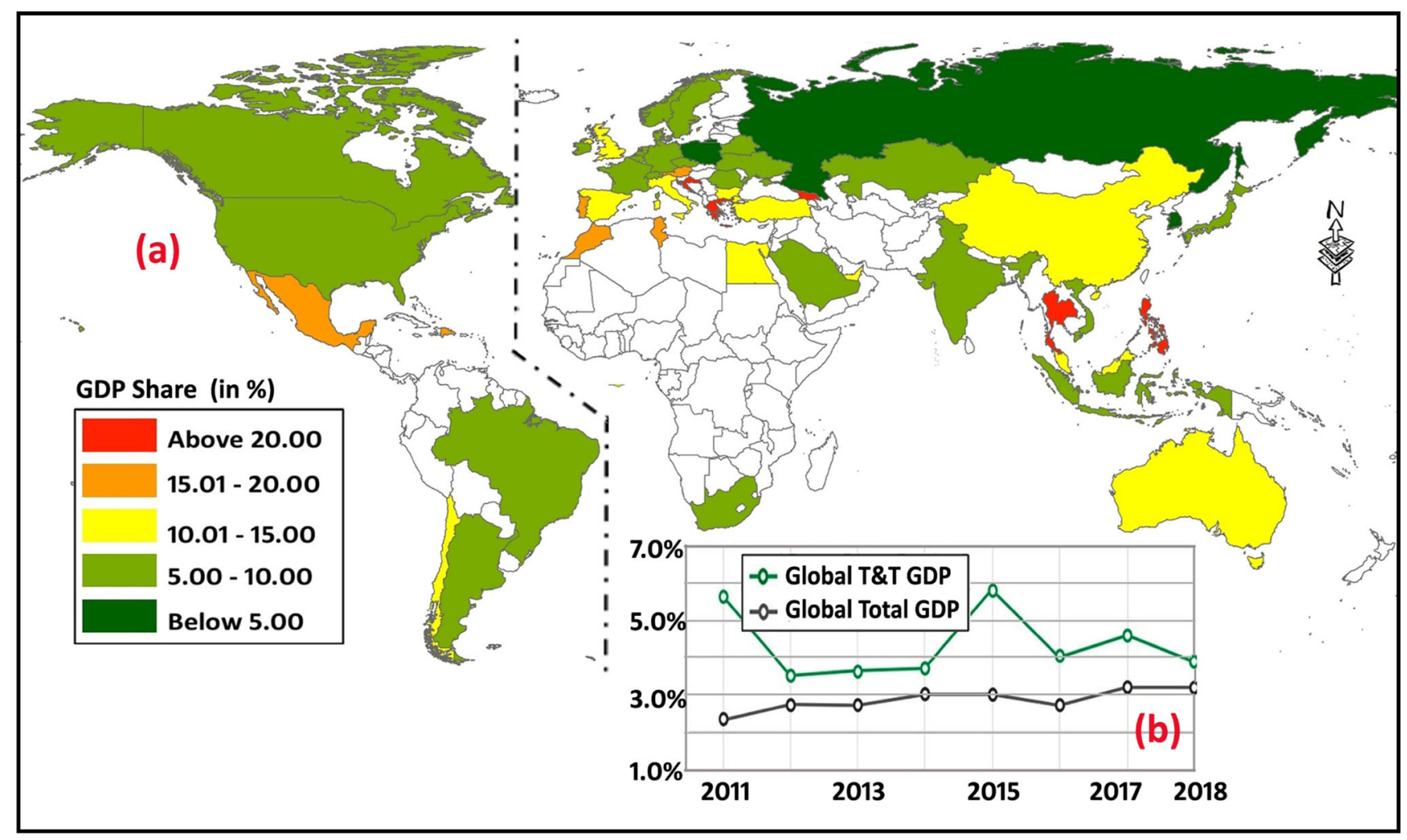

Fig. 4 Impact of tourism on country's GDP: a country-wise GDP share (in \%) during 2018 from travel and tourism sector and b global GDP growth (in \%) from travel and tourism (T\&T) sector and total economic GDP growth during 2011-2018

market in Schengen has somehow boosted the travel demand in Europe though second wave of Covid-19 pandemic has re-imposed the travel restriction. International arrivals reduced an extraordinary manner with $95 \%$ during the second quarter of 2020 with a drop of $28 \%$ in the first quarter. Due to travel restrictions and lockdown in the several tourist places make such fall, which was unprecedented. According to estimation by UNWTO (United Nation World Tourism Organisation), during JanuaryAugust 2020, a global decline of nearly $70 \%$ will reach as per international tourist demand with a loss of 730US\$ billion. This results depict the loss will be eight times to the great recession in 2009. When the regional insights have been taken into consideration, Asia-Pacific has faced the hardest hit with a decline of $72 \%$ of tourist arrival and Europe with $66 \%$ of tourist arrival decline following by America $(-55 \%)$ and Middle East $(-57 \%)$.

The World's most visited destination-Europe has been experienced a fall of $66 \%$ during first and second quarters (Jan-June) of 2020 due to travel ban and lockdown of tourists places due to ongoing pandemic (see Fig. 2). The travel and tourism industry has been hit hard due to this extraordinary situation arose from January-February onwards. Somehow domestic tourism activity has been resumed in some portion of Europe with cautious approach with cross-border travel. Thus by sub-region basis, in
Southern and Mediterranean region a decline of $72 \%$ has been found with Western and Central Europe of-63\% and $-62 \%$ respectively (see Table 3 ). From 16 March to 30 June 2020 a travel restriction from third country to EU countries has been extended further restricted free movement from 4 September 2020 again [37]. Such falloffs of tourist make a huge down fall in the country's economy which has a social costs and benefits. Actually increase in GDF directly improves the social benefits among the population by tourism receipts. Due to decline of tourism the burden on the government has increase a lot and for the survival strategy several countries have announced different package to retain the service in this sector. Such a burden easily accumulates social cost which has been found immensely during 2020 .

Due to Covid-19, the major setback has been found in Asia Pacific region with record decline of $72 \%$ tourist arrival for the period of January-June in respect of last year. In Asia-Pacific region, North-East and South-East Asia attract much more than the other parts of the region and during February, 2020, a massive drop in international tourist has already been felt. North-East Asia has been evidenced a record decline $(-83 \%)$ and this part shows the highest decline in sub-regional aspect to the Asia pacific region (see Fig. 3). As Wuhan in China has been addressed as the source point of Covid-19 and WHO 
release press brief about Covid-19 as pandemic and $\mathrm{H} 2 \mathrm{H}$ (human to human) transformation possibility, North East and South East sub region faced a sharp decline in the second in the second Quarter (April-June) on International tourist arrival. According to STR dataset, opening of $40 \%$ to $45 \%$ hotels have been reputed during July 2020 . In case of domestic travel aspect, China has been reached nearly 90\% in July, 2019 comparison as the opening of different tourist spots.

America region is complied with North America, Central America, Caribbean and South American sub regions. According to UNWTO dataset, a sharp fall of $55 \%$ of international tourist arrival has been found during JanuaryJune, 2020 in comparison to last year [40]. As US has been experiencing the highest Covid-9 cases, 50.5\% of tourist arrival has been declined with approximately 48 million and it has resulted a loss of US\$115 billion. USA has closed its border with Mexico and Canada except nonessential travel up to 21 September. Caribbean, one of the major destinations of international tourist, has reported during June-July with implementing health and hygiene protocols. According to STR data, San Diego has found $41.1 \%$ and New Orleans with $28 \%$ of hotels occupancy respectively in September 2020. US hotels have been close down during March-May in number of 3141 in temporary which was further reopened with 1842 hotels after May 15, 2020. Revenue generation has been critical due to such closure and assumed nearly $48 \%$ of increase during 2020 .

During January-June, 2020, Africa has experienced a decrease of $57 \%$ and Middle East at about 56.45 with 18 million and 19 million of International tourist Y-O-Y. Recently Egypt from Middle East Tourism region has started international flights (from 1st July, 2020) with the campaign of 'Saudi Summer'; According to UNWTO report, 26 destinations in African region and 5 destinations in Middle region has caused the travel restriction to minimize the loss which has been faced during first two quarters.

\subsection{Tourism decline due to SARS-CoV-2-a country wise assessment}

This year due to Covid-19 pandemic, global tourism has been hit hard with a loss of nearly 320 billion US $\$$ and by the end of this year more than 120 million jobs related to travel and tourism industry will be at risk. Nearly 45 million populations have been affected due to this ongoing pandemic and death toll rises nearly 12 million. In such situation, travel and tourism sectors, especially arrivals of international tourists have been declined at large scale

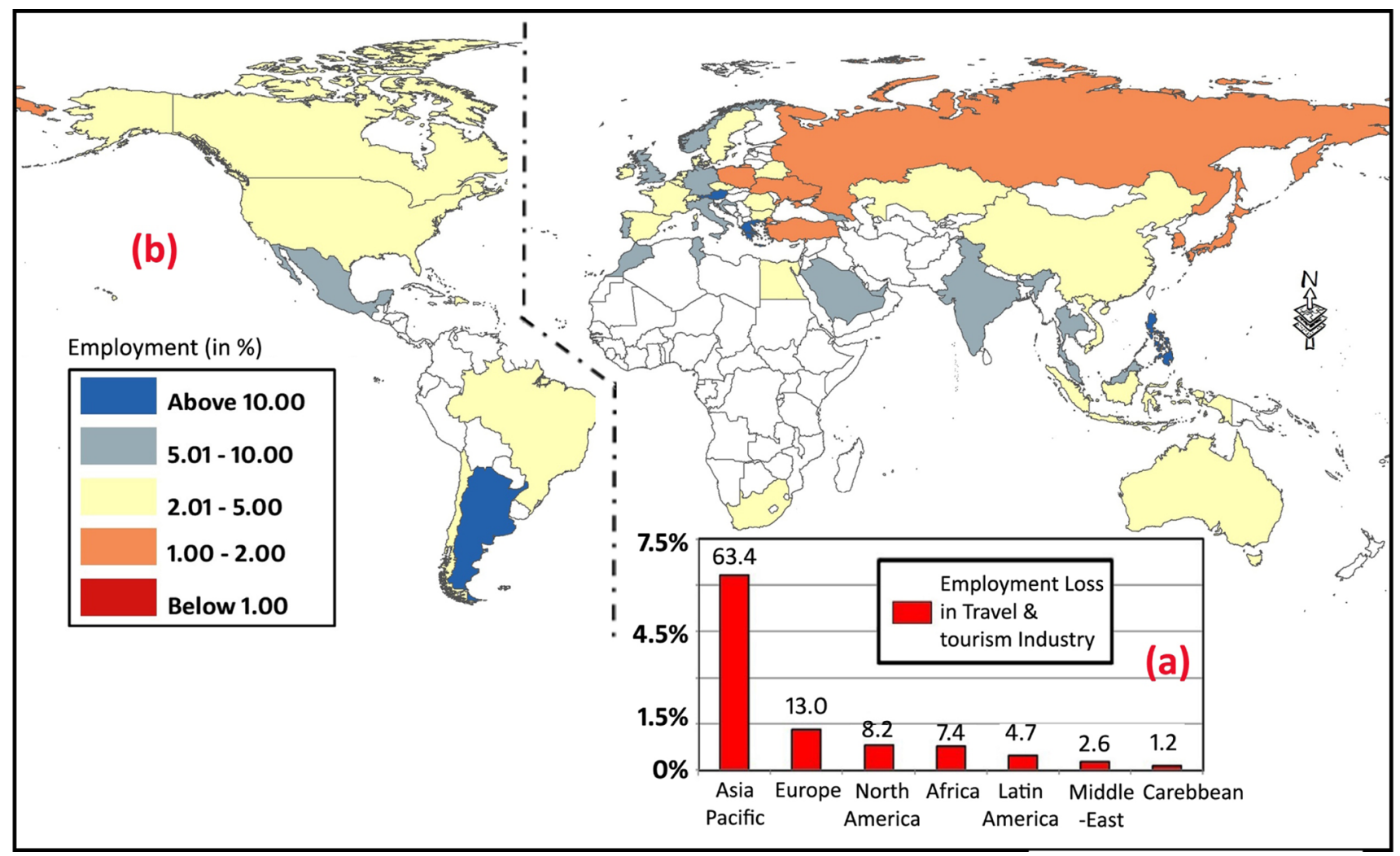

Fig. 5 Nature of employment from travel and tourism sector: a UNWTO region-wise expected employment loss (in \%) in travel and tourism sector (T\&T) SARS-CoV-2 b country-wise employment (in \%) in travel and tourism sector during 2019 


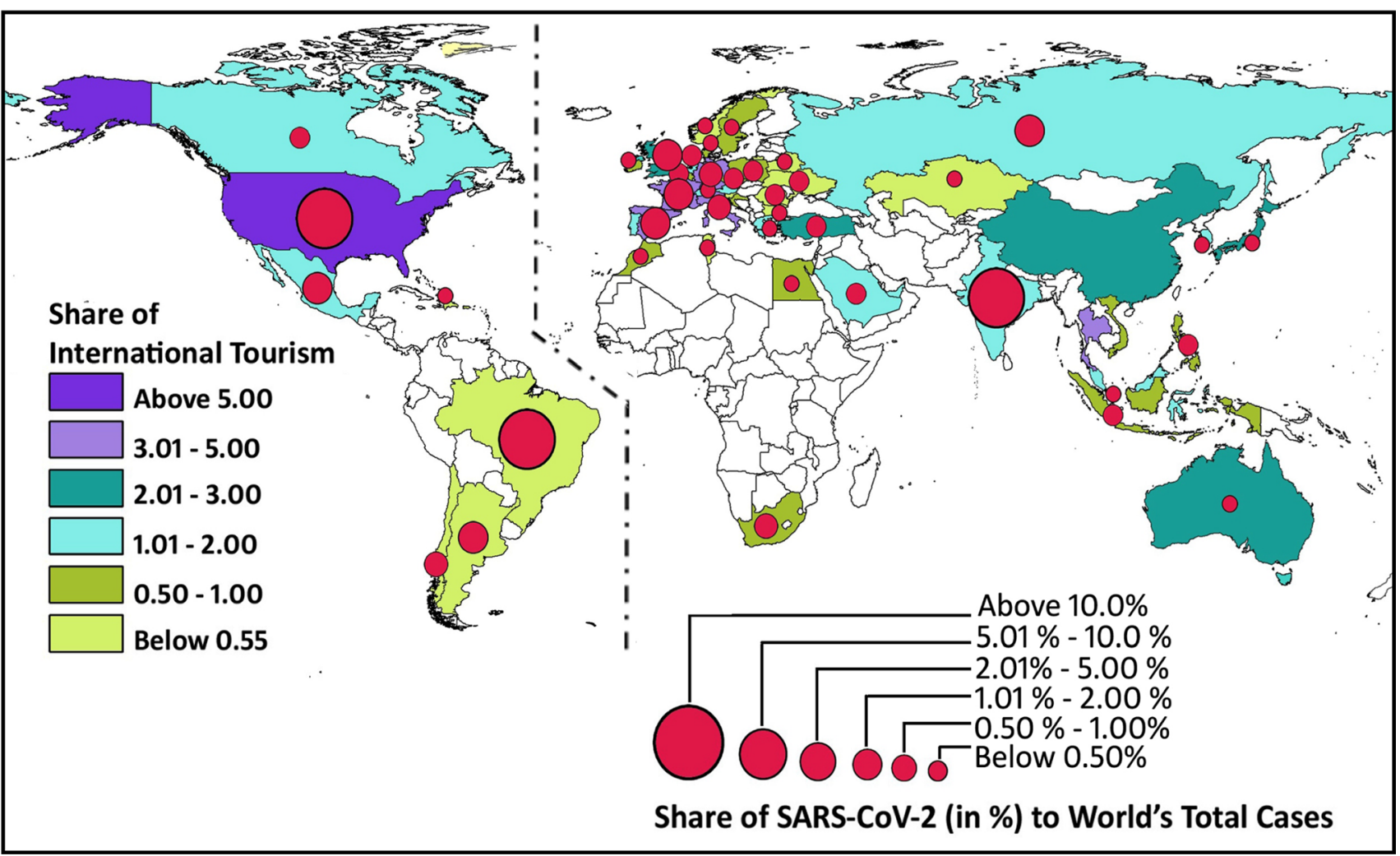

Fig. 6 Country-wise international tourist arrival (in \%) during 2019 and infected cases of SARS-CoV-2 (in \%)

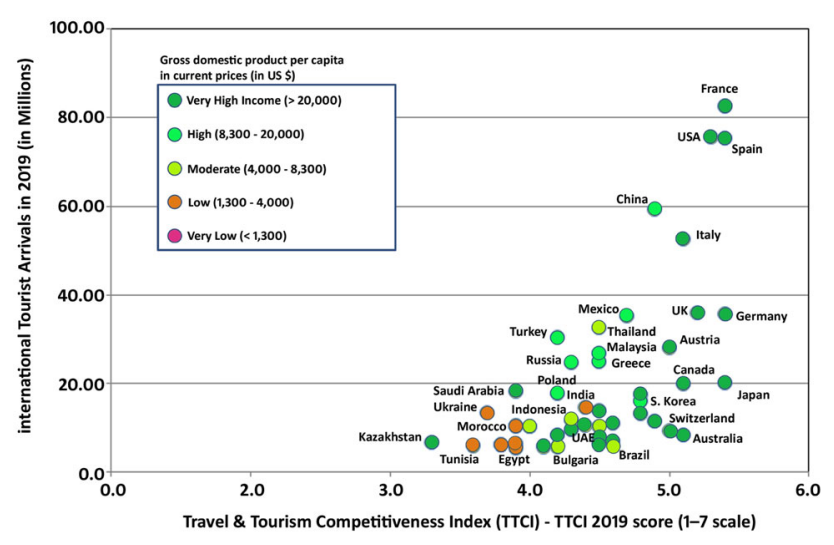

Fig. 7 Scatter plot showing country level (per-capita GDP wise) relation between international tourist arrival (in million) during 2019 and travel \& tourism competitiveness index (in 1-7 Scale)

throughout the global (nearly $65.3 \%$ Y-O-Y). Countries experienced large tourism growth during last 5-10 years faced a serious challenge with the shutdown of tourist destinations and cancellation of flights. In this perspective first 50 countries have been taken in to consideration (2018-19) to assessing the impact of tourism on economy. We have taken five indicators, i.e. (i) international tourist arrival, (ii) share of tourism sectors countries GDP, (iii) Job markets (formal and non-formal) in travel and tourism sectors, (iv) tourism receipts at current price and (v) depending on tourism. Initially AHP method has been applied after a vivid literature review and weightage has been calculated for each of the indicators. Then with the help of normalised value, weightage has been multiplied and added.

According to WTTC report, travel and tourism industry has contributed nearly us $\$ 8.8$ trillion to global economy which is equal to $10.4 \%$ of global GDP [41]. Across the world meanly 320 million people has been engaged in this sector with an economic growth of $3.2 \%$. In 2018, USA and China has contributed nearly $35.2 \%$ of world total travel and tourism GDP followed by Japan, Germany and UK. This scenario has been also evident in world's fastest growing countries like Ethiopia $(+48.6 \%)$, Ecuador $(+21.6 \%)$, Egypt $(+16.5 \%)$ and Turkey $(+15.0 \%)$, Thailand (22.23\%), Greece (21.52\%), Croatia (25.075), Georgia (33.90\%), Philippines (24.43\%) has been found more than 1/5 part of country's GDP from travel and tourism sector (see Fig. 4a). This ongoing pandemic has ruined such countries which have been growing very fast with such economic sector.

In respect of job creation, travel and tourism industry has been found the most dynamic engine for job creation worldwide [42]. This sector create one in every five all net new job creation across world. The present pandemic predicted a loss of 100.8 million jobs during 2020 in the 
Table 4 Dataset for assessment and develop Tourism Impact on Economy (TIE) Index

\begin{tabular}{|c|c|c|c|c|c|c|c|c|c|}
\hline Sl. No & Countries & GDP share & Jobs & Tourists & Dependency rate & Tourism receipts & TTCI & Inter. Tourism Receipts & TIE \\
\hline 1 & France & 9.53 & 4.36 & 82.57 & 9.50 & 73,125 & 5.40 & -49.40 & 0.35 \\
\hline 2 & USA & 7.83 & 3.73 & 75.61 & 7.80 & 256,145 & 5.3 & -50.50 & 0.35 \\
\hline 3 & Spain & 14.72 & 4.42 & 75.31 & 14.70 & 81,250 & 5.4 & -70.60 & 0.41 \\
\hline 4 & China & 10.93 & 3.77 & 59.27 & 10.90 & 40,386 & 4.9 & -40.90 & 0.29 \\
\hline 5 & Italy & 13.33 & 5.99 & 52.37 & 13.30 & 51,602 & 5.1 & -67.70 & 0.33 \\
\hline 6 & UK & 10.96 & 5.24 & 35.81 & 11.00 & 48,515 & 5.2 & -30.20 & 0.25 \\
\hline 7 & Germany & 8.50 & 6.92 & 35.55 & 8.50 & 60,260 & 5.4 & -43.60 & 0.23 \\
\hline 8 & Mexico & 17.48 & 8.85 & 35.08 & 17.50 & 23,802 & 4.7 & -50.00 & 0.36 \\
\hline 9 & Thailand & 22.23 & 6.66 & 32.53 & 22.20 & 65,242 & 4.5 & -42.90 & 0.41 \\
\hline 10 & Turkey & 12.83 & 1.84 & 30.29 & 12.80 & 37,140 & 4.2 & -67.60 & 0.23 \\
\hline 11 & Austria & 15.54 & 11.02 & 28.02 & 15.50 & 25,411 & 5 & -9.70 & 0.33 \\
\hline 12 & Malaysia & 13.30 & 6.63 & 26.76 & 13.30 & 21,774 & 4.5 & -69.40 & 0.26 \\
\hline 13 & Greece & 21.52 & 10.59 & 24.80 & 21.50 & 21,594 & 4.5 & -87.50 & 0.41 \\
\hline 14 & Russia & 4.89 & 1.15 & 24.57 & 4.90 & 18,670 & 4.3 & -9.20 & 0.09 \\
\hline 15 & Japan & 7.60 & 1.94 & 20.04 & 7.70 & 45,276 & 5.4 & -69.60 & 0.13 \\
\hline 16 & Canada & 6.58 & 3.97 & 19.82 & 6.60 & 21,978 & 5.1 & -41.40 & 0.12 \\
\hline 17 & Saudi Arabia & 9.25 & 7.56 & 18.05 & 9.30 & 16,975 & 3.9 & -15.40 & 0.19 \\
\hline 18 & Poland & 4.53 & 1.96 & 17.47 & 4.50 & 15,778 & 4.2 & -10.10 & 0.07 \\
\hline 19 & South Korea & 2.70 & 1.14 & 17.24 & 2.80 & 19,856 & 4.8 & -59.10 & 0.04 \\
\hline 20 & Netherlands & 5.04 & 4.74 & 15.83 & 5.00 & 25,850 & 4.8 & -15.60 & 0.10 \\
\hline 21 & India & 9.26 & 5.39 & 14.57 & 9.30 & 29,143 & 4.4 & -15.00 & 0.16 \\
\hline 22 & Croatia & 25.07 & 7.99 & 13.81 & 25.10 & 12,075 & 4.5 & -19.40 & 0.40 \\
\hline 23 & Ukraine & 5.27 & 1.17 & 13.33 & 5.30 & 2269 & 3.7 & -12.20 & 0.06 \\
\hline 24 & Singapore & 4.29 & 5.11 & 12.91 & 10.20 & 20,416 & 4.8 & -60.80 & 0.09 \\
\hline 25 & Indonesia & 6.07 & 3.91 & 11.52 & 6.10 & 15,600 & 4.3 & -61.10 & 0.09 \\
\hline 26 & Portugal & 19.88 & 7.62 & 11.22 & 19.90 & 24,105 & 4.9 & -54.40 & 0.32 \\
\hline 27 & Denmark & 8.13 & 2.43 & 10.78 & 8.10 & 9097 & 4.6 & -60.20 & 0.11 \\
\hline 28 & Morocco & 18.88 & 7.71 & 10.33 & 18.90 & 9523 & 3.9 & -44.10 & 0.30 \\
\hline 29 & UAE & 10.84 & 8.02 & 10.33 & 10.80 & 21,390 & 4.4 & -11.20 & 0.19 \\
\hline 30 & Romania & 5.34 & 2.34 & 10.22 & 5.30 & 3261 & 4 & -18.67 & 0.06 \\
\hline 31 & Ireland & 6.51 & 2.36 & 10.10 & 6.50 & 14,654 & 4.5 & -63.60 & 0.08 \\
\hline 32 & South Africa & 8.76 & 3.27 & 10.04 & 8.80 & 9789 & 4 & -9.70 & 0.12 \\
\hline 33 & Vietnam & 8.95 & 4.70 & 10.01 & 9.00 & 10,080 & 3.9 & -56.80 & 0.13 \\
\hline 34 & Belarus & 6.41 & 4.26 & 9.42 & 6.40 & 1221 & 3.8 & -0.01 & 0.09 \\
\hline 35 & Czech Republic & 7.71 & 4.13 & 9.32 & 7.70 & 8291 & 4.3 & -9.70 & 0.11 \\
\hline 36 & Switzerland & 8.76 & 3.78 & 9.21 & 8.80 & 20,276 & 5 & -8.60 & 0.12 \\
\hline 37 & Australia & 10.86 & 4.70 & 8.26 & 10.90 & 47,327 & 5.1 & -27.30 & 0.17 \\
\hline 38 & Bulgaria & 11.79 & 3.80 & 8.25 & 11.80 & 5072 & 4.2 & -25.93 & 0.16 \\
\hline 39 & Belgium & 5.40 & 2.29 & 7.48 & 5.40 & 10,381 & 4.5 & 1.10 & 0.06 \\
\hline 40 & Sweden & 9.76 & 3.74 & 6.78 & 9.80 & 14,926 & 4.6 & -45.60 & 0.13 \\
\hline 41 & Brazil & 8.12 & 2.50 & 6.58 & 8.10 & 6324 & 4.5 & -43.60 & 0.09 \\
\hline 42 & Kazakhstan & 5.53 & 2.21 & 6.51 & 5.50 & 2651 & 3.3 & -5.11 & 0.05 \\
\hline 43 & Georgia & 33.90 & 7.81 & 6.36 & 33.90 & 3518 & 3.9 & -8.53 & 0.50 \\
\hline 44 & Philippines & 24.43 & 13.86 & 5.97 & 24.40 & 9730 & 3.8 & -35.00 & 0.42 \\
\hline 45 & Dominican Rep & 16.85 & 4.66 & 5.96 & 16.90 & 7561 & 3.8 & -59.90 & 0.23 \\
\hline 46 & Norway & 9.04 & 6.06 & 5.96 & 9.00 & 7096 & 4.6 & -30.01 & 0.14 \\
\hline 47 & Tunisia & 16.05 & 6.89 & 5.72 & 16.00 & 2320 & 3.6 & -65.72 & 0.24 \\
\hline 48 & Chile & 10.54 & 3.44 & 5.64 & 10.50 & 3972 & 4.1 & 16.62 & 0.13 \\
\hline
\end{tabular}


Table 4 continued

\begin{tabular}{llcccccrrr}
\hline S1. No & Countries & GDP share & Jobs & Tourists & Dependency rate & Tourism receipts & TTCI & Inter. Tourism Receipts & TIE \\
\hline 49 & Argentina & 9.73 & 34.39 & 5.56 & 9.70 & 5999 & 4.2 & -9.75 & 0.39 \\
50 & Egypt & 11.86 & 3.96 & 5.26 & 11.90 & 12,704 & 3.9 & -11.40 & 0.16 \\
\hline
\end{tabular}

N.B. GDP Share (in \%), 2019, Tourists (in million), Dependency Rate on Tourism-2019, Tourism Receipts (in '000,000 Current US \$)—2018, TTCI = Travel \& Tourism Competitiveness Index, International Tourism Receipts (US\$ billion) during Q1, Q2 (2020) and TIE = Tourism Impact on Economy

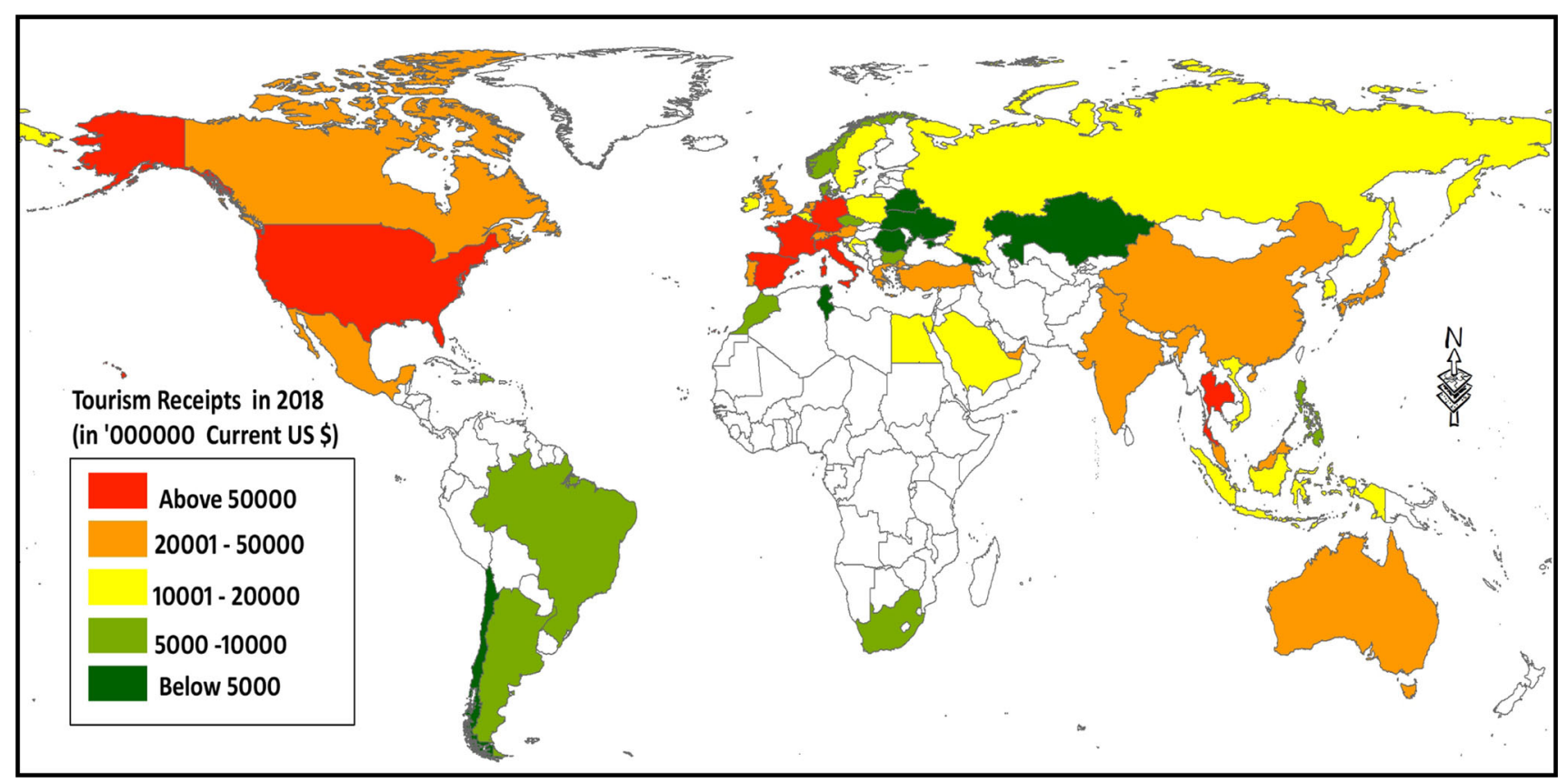

Fig. 8 Country-wise tourism receipts during 2018 (in '000,000 US \$)

global travel and tourism market (see Fig. 5b). AsiaPacific region will see the biggest loss of 63.4 million jobs followed by Europe with 13 million as forecasted by UNWTO. Greece, Portugal, UAE has created remarkable new job with $71 \%, 60 \%$ and $47 \%$ respectively in 2018 . In respect of travel and tourism contribution to employment, Argentina (33.39\%), Philippines (13.86\%), Australia $(11.0 \%)$ and Greece $(10.59 \%)$ are the leading countries having large member of absorption (see Fig. 5b). In this study this criteria has been evaluated as the second most important variable as the remittance will upheld the quality of life among the people of the country poverty reduction which has also been suggested in SDGs. The ongoing pandemic started from January-February 2020 has been hit hard due to closure of hotels and resort in every tourist destinations [41]. According to UNWTO report up to April 20, 2020, 97 destinations have been totally or partially close down is response to ongoing pandemic situation.
UNWTO [37] has assessed record arrivals of international tourists at about 1.5 billion with an anticipation of $4 \%$ increase in 2020 . This industry employs one in every 10 person globally and making an account of $7 \%$ global trade. During 2019 dataset by UNWTO, France found top (see Fig. 6) with 82.57 million tourist arrival following USA and Spain with $75.61 \%$ and $75.31 \%$ million tourist respectively. In recent TTCI (Travel and Tourism Competitiveness Index) report from World Economic Forum it is clear most of the advanced countries in global found high rating in TTCI and countries have placed in first 10 places from Europe. Due to ongoing pandemic situation the loss has been unprecedented or those countries along with USA, Japan, Canada and Australia [42]. Most of the low to moderate income group (as mentioned by World Bank) countries except Thailand) having a tourist arrival of below 20 million (see Fig. 7) in last year. Most hard hit area has been found as Asia- Pacific (decline of $72.2 \% \mathrm{Y}-\mathrm{O}-\mathrm{Y}$ ) as 


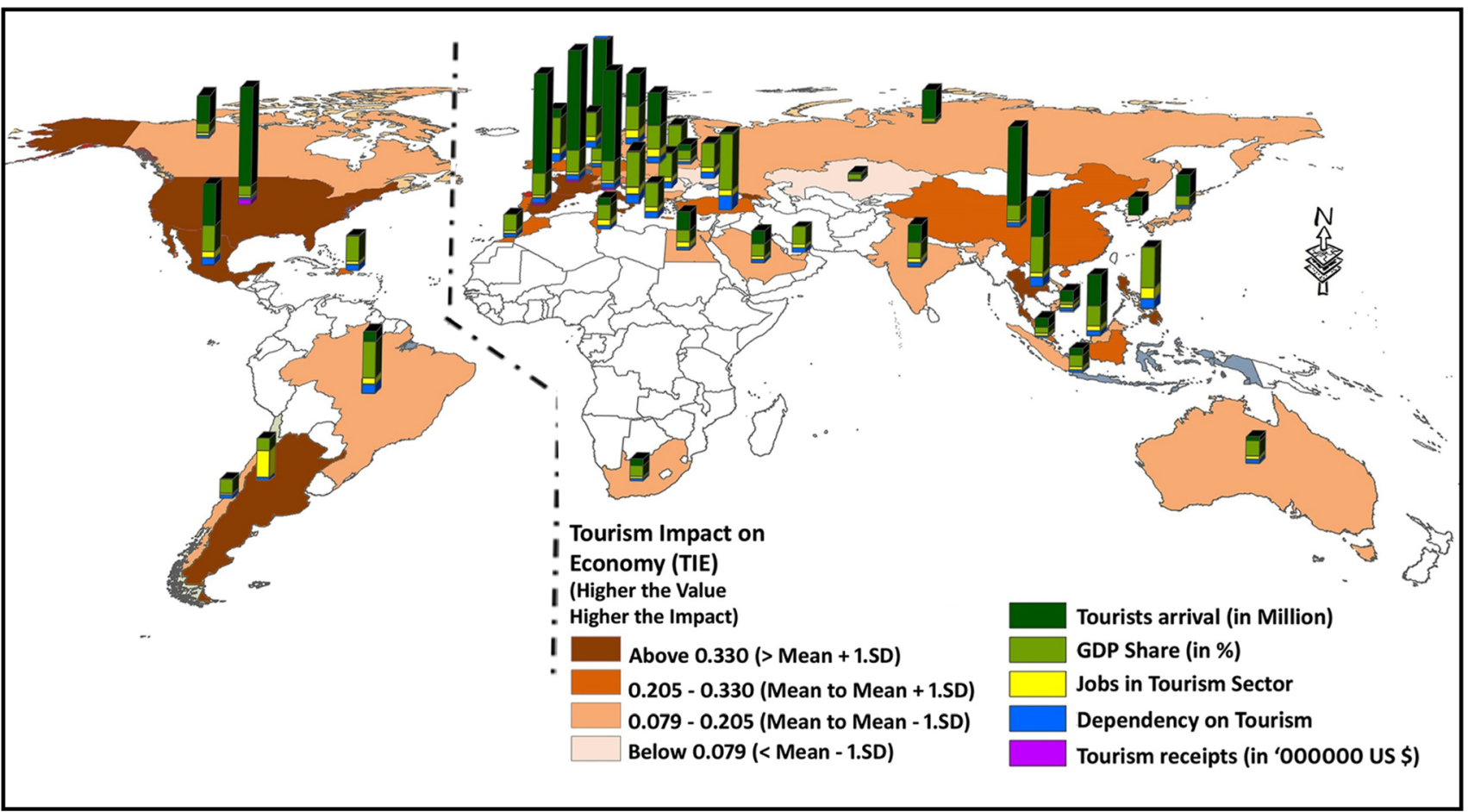

Fig. 9 Country-wise Tourism Impact on Economy (TIE) based on the selected indicators

Fig. 10 Box plot showing relationship between countrywise Tourism Impact on Economy and international tourism receipt loss during Q1 and Q2 (2020)

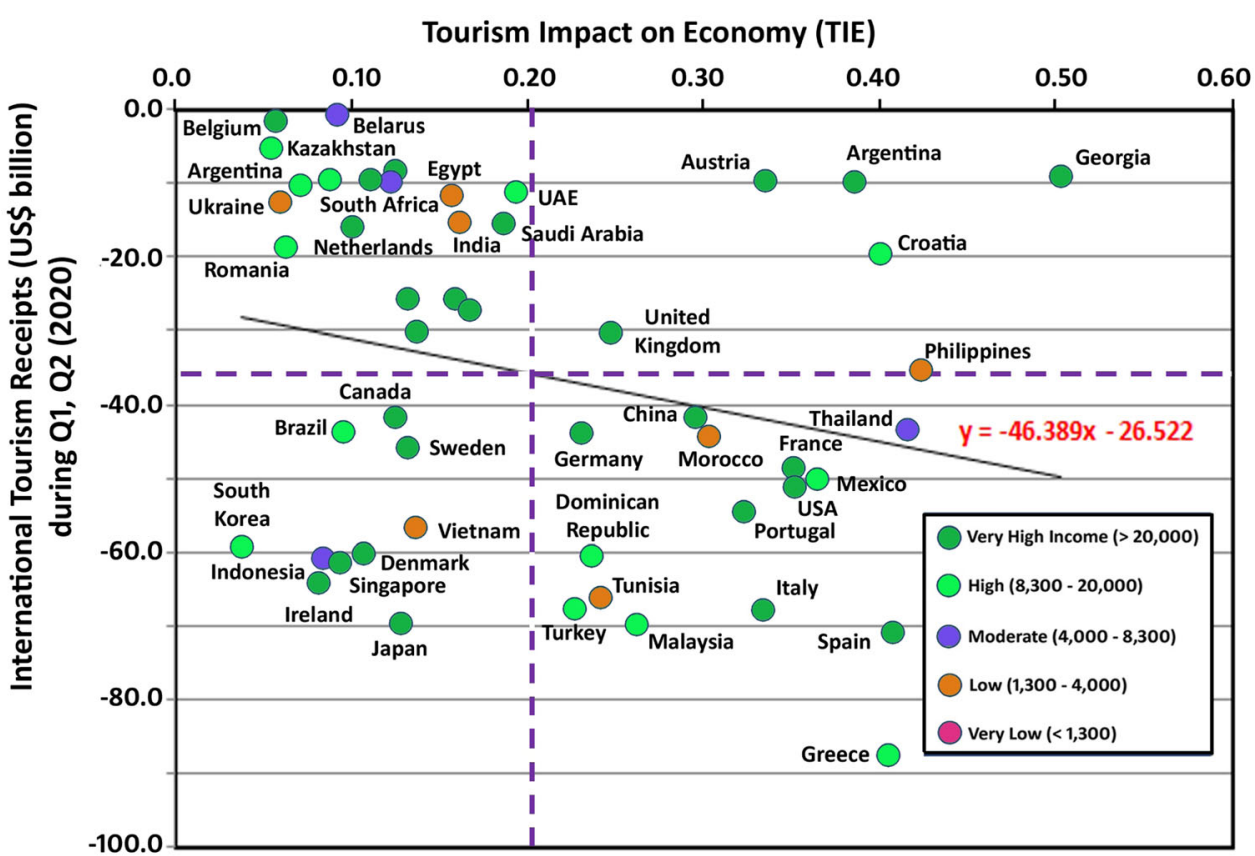

the source of this pandemic was Asia. Travel bar, cancellation of international flight, prologue lockdown make a sharp decline of tourism industry in every region globally (see Table 4).

International tourism receipt is one of the importance issues as this criterion relates the expenditures by international inbound visitors including payments for international carriers. As this is the direct measure of economic contribution and upheld the country's economy (see Fig. 8). Numbers of developed countries have opened up with this sector. According to UNWTO World Tourism barometer, international tourism is trying to recover the 2009 recession period with an estimation of US \$ 1030 billion loss. But the recent ongoing Covid-19 situation and ban on travel and 
tourism can make a fall of nearly $62 \%$ as predicted by UNWTO. Such fall has been found during SARS-2003 when International tourism receipt was US\$ 554 billion. It has also been estimated that, with a decline of US\$ 850 million to US\$ 1.1 billion international tourist, globally US\$ 910 billion to US\$ 1.2 trillion loss can be experienced in export revenues from travel and tourism sector [43].

Tourism dependency Index is a straight forward measure as developed by World Bank [41]. It implies that a country's dependency level forwards travel and tourism sector which has hardly hit the ongoing pandemic, when the $100 \%$ tourist destinations have introduced the travel restrictions [43]. Nearly $30 \%$ if international flights to top tourism destinations suspended totally $18 \%$ have been closing the border in more differentiated manner till the end of April 2020. The scenario has hit hard to those countries which tourism dependency index found more than 15. Countries like Thailand, Italy, Greece, Croatia, Malaysia have been faced a huge decline of international tourist and these country have a high level of tourism dependency in their national level GDP.

With the help of the above discussed indicators we have developed an index named as 'Tourism Impact on Economy' (TIE) to study the nature of country which is ranked in first 50 places in respect of international tourist arrival. With the help of the assessed index value, four class have been developed, i.e. very high impact $(>$ mean +1 sd), high impact (mean to mean $+1 \mathrm{sd}$ ), moderately impact (mean to mean-1sd) and low impact $<$ mean-1sd).

From the analysis, it is clear the countries having higher GDP share from tourism and travel sector and jobs in Travel and Tourism sector found as very highly impact with a loss of 41.75 US \$ billion during Q1 and Q2 period of 2020 as estimated by UNWTO (see Table 4). A positive Correlation has been found with the TIE index and loss Estimation (in billion US \$) which signifies that higher the tourism receipt and GDP share from travel and tourism sector has faced a hard hit than the other countries (see Fig. 9). Spain, USA, France, Italy are found in the first group of impact. In case of higher impact group, China, Malaysia, UK, Germany, Turkey have been placed and except Morocco and Tunisia, all the countries are from high to very high-income group. Morocco and Tunisia from Northern Africa has found as emerging countries from this sub region and in global aspect also.

Nearly $50 \%$ of the assessed countries ( 23 out of 50 ) have been positioned in the moderately impact class and India, Vietnam, Egypt has been found in this class. As India has nearly 27.5 million population associated direct or indirectly with travel and tourism sector, the loss has been estimated nearly 15 billion US \$ during Jan-June 2020 by UNWTO. It is important to note that near about 31.20 billion US $\$$ has been estimated as loss from tourism sector from this moderately impact group (see Fig. 10). In consideration of low impact group, South Korea has placed in Rank 50 with a loss approximation of US \$ 59.10. In this group 6 countries combined contribute nearly $5 \%$ of Covid-19 cases to total cases and found average loss of 17.71 US \$. The figure has been up rise as South Korea $(-59.1)$ and Romania $(-18.67)$ has much tourism receipt than the other countries.

\section{Conclusion}

The study tries to estimate the impact of Covid-19 over tourism sector for 50 nations. Considering such estimation, the results of AHP elucidates a clear understanding of ranking of the countries in terms of the impact assessment. The countries like Georgia, Philippines, Thailand, Spain, Greece, Croatia are the major shock affected countries and it is also observes that a lot of dependencies of these countries are performed circulating tourism. The tourism dependency may not be severe for those countries, which manage the spreading of the disease meticulously from the very initial period. The study does not consider the average temperature role in such understanding and that can be used as future scope of research.

Acknowledgements The authors acknowledge knoema, United Nation World Tourism Organisation, World Bank, World Travel and Tourism Council for providing data support for the study. All the authors would like to thank the editor and three anonymous reviewers for their comments and suggestions.

Funding This work has not been supported by any State or Central Government funding agencies.

\section{Declaration}

Conflict of interest The authors declare that there is no conflict of interest.

\section{References}

1. Yang, Y., Zhang, H., \& Chen, X. (2020). Coronavirus pandemic and tourism: Dynamic stochastic general equilibrium modeling of infectious disease outbreak. Annals of Tourism Research. https:// doi.org/10.1016/j.annals.2020.102913

2. WHO (2020). Coronavirus disease (COVID-19) outbreak situation. World Health Organization (WHO). Retrieved from https:// www.who.int/ emergenci es/diseases/novelcoronavirus2019https://www.who.int/docs/defaultsource/coronaviruse/ situation-reports/20200328-sitrep-68-covid-19.pdf?sfvrsn= 384bc74c_2(Coronavirus disease 2019 (COVID-19) Situation Report-68).

3. Richter, L. K. (2003). International tourism and its global public health consequences. Journal of Travel Research, 41(4), 340-347. 
4. GitHub, Oxford. (2020). Oxford Covid-19 government response tracker (OxCGRT). Retrieved from. https://github.com/ OxCGRT/covid-policy-tracker.

5. Oganisation for Economic Cooperation and Development. (2020). OECD economic outlook. Interim Report. https://doi.org/ 10.1787/7969896b-en.

6. World Bank. (2020a). Air transport, passengers carried. Retrieved April 4, 2020, from https://data.worldbank.org/indicator/is.air. psgr.

7. Brown, A., Ahmad, S., Beck, C., \& Nguyen-Van-Tam, J. (2016). The roles of transportation and transportation hubs in the propagation of influenza and coronaviruses: A systematic review. Journal of Travel Medicine. https://doi.org/10.1093/jtm/tav002

8. Mallapaty, S. (2020). What the cruise-ship outbreaks reveal about COVID-19. Nature, 580, 18.

9. Farzanegan, M. R., Gholipour, H. F., Feizi, M., Nunkoo, R., \& Andargoli, A. E. (2020). International tourism and outbreak of coronavirus (COVID-19): A cross-country analysis. Journal of Travel Research. https://doi.org/10.1177/0047287520931593

10. Hilsenrath, J. (2020). Global viral outbreaks like coronavirus, once rare, will become more common. The Wall Street Journal. Retrieved from https://www.wsj.com/articles/viral-outbreaksonce-rare-become-part-of-the-global-landscape-11583455309.

11. Lindberg, K., Andersson, T. D., \& Dellaert, B. G. (2001). Tourism development: Assessing social gains and losses. Annals of Tourism Research, 28(4), 1010-1030.

12. Torre, A., \& Scarborough, H. (2017). Reconsidering the estimation of the economic impact of cultural tourism. Tourism Management, 59, 621-629.

13. Sharifpour, M., Walters, G., \& Ritchie, B. W. (2014). Risk perception, prior knowledge, and willingness to travel: Investigating the Australian tourist market's risk perceptions towards the Middle East. Journal of Vacation Marketing, 20(2), 111-123.

14. Song, H., Livat, F., \& Ye, S. (2019). Effects of terrorist attacks on tourist flows to France: Is wine tourism a substitute for urban tourism? Journal of Destination Marketing \& Management. https://doi.org/10.1016/j.jdmm.2019.100385

15. Pongsiri, M. J., Roman, J., Ezenwa, V. O., Goldberg, T. L., Koren, H. S., Newbold, S. C., Ostfeld, R. S., Pattanayak, S. K., \& Salkeld, D. J. (2009). Biodiversity loss affects global disease ecology. BioScience, 59(11), 945-954. https://doi.org/10.1525/ bio.2009.59.11.6

16. Labonte, R., Mohindra, K., \& Schrecker, T. (2011). The growing impact of globalization for health and public health practice. Annual Review of Public Health, 32(1), 263-283. https://doi.org/ 10.1146/annurev-publhealth-031210-101225

17. Malczewski, J. (2004). GIS-based land-use suitability analysis: A critical overview. Progress in Planning, 62, 3-65.

18. Aly, M. H., Giardino, J. R., \& Klein, A. G. (2005). Suitability assessment for New Minia City, Egypt: a GIS approach to engineering geology. Environmental and Engineering Geoscience, 11(3), 259-269.

19. Banai, R. (2005). Land resource sustainability for urban development: Spatial decision support system prototype. Environmental Management, 36(2), 282-296.

20. Collins, M. G., Steiner, F. R., \& Rushman, M. J. (2001). Land-use suitability analysis in the United States: historical development and promising technological achievements. Environmental Management, 28(5), 611-621.

21. Saaty, T. L. (1977). A scaling method for priorities in hierarchical structures. Journal of Mathematical Psychology, 15(3), 234-281.

22. Aliperti, G., Sandholz, S., Hagenlocher, M., Rizzi, F., Frey, M., \& Garschagen, M. (2019). Tourism, crisis, disaster: An interdisciplinary approach. Annals of Tourism Research. https://doi. org/10.1016/j.annals.2019.102808
23. Cró, S., \& Martins, A. M. (2017). Structural breaks in international tourism demand: Are they caused by crises or disasters? Tourism Management, 63, 3-9.

24. Easterling, D. S. (2005). The residents' perspective in tourism research: A review and synthesis. Journal of Travel \& Tourism Marketing, 17(4), 45-62.

25. Kuo, H. I., Chen, C. C., Tseng, W. C., Ju, L. F., \& Huang, B. W. (2008). Assessing impacts of SARS and avian flu on international tourism demand to Asia. Tourism Management, 29(5), 917-928.

26. Sio-Chong, U., \& So, Y. C. (2020). The impacts of financial and non-financial crises on tourism: Evidence from Macao and Hong Kong. Tourism Management Perspectives. https://doi.org/10. 1016/j.tmp.2019.100628

27. Wang, Y. S. (2009). The impact of crisis events and macroeconomic activity on Taiwan's international inbound tourism demand. Tourism Management, 30(1), 75-82.

28. Li, J., Nguyen, T. H. H., Coca-Stefaniak, J.A. (2020). Coronavirus impacts on post-pandemic planned travel behaviours. Annals of Tourism Research (In press, corrected proof Available online 28 May 2020 Article 102964).

29. Reddy, M. V., Boyd, S. W., \& Nica, M. (2020). Towards a postconflict tourism recovery framework. Annals of Tourism Research. https://doi.org/10.1016/j.annals.2020.102940

30. Ritchie, B. W. (2008). Tourism disaster planning and management: From response and recovery to reduction and readiness. Current Issues in Tourism, 11(4), 315-348.

31. Scott, N., \& Laws, E. (2006). Tourism crises and disasters: Enhancing understanding of system impacts. Journal of Travel \& Tourism Marketing, 19(2-3), 149-158.

32. World Bank. (2020b). International tourism, number of arrivals. Retrieved April 4, 2020, from https://data.worldbank.org/indi cator/ST.INT.ARVL.

33. Business Insider. (2020). UK airline Flybe declares bankruptcy as coronavirus dooms the already struggling carrier. Retrieved March 31, 2020, from https://www.Busin essinsider.de/international/uk-airline-flybe-declares-bankruptcy-flights-grounded$2020-3 / ? \mathrm{r}=\mathrm{US} \& \mathrm{IR}=\mathrm{T}$.

34. UNWTO. (2020a). COVID-19: UNWTO calls on tourism to be part of recovery plans. https://www.unwto.org/news/ covid-19unwto-calls-on-tourism-to-be-part-of-recovery-plans.

35. UNWTO. (2020b). International tourist arrivals could fall by 20-30\% in 2020. Retrieved April 5, 2020, from https://www. unwto.org/news/international-tourism-arrivals-could-fall-in2020.

36. Knoema. (2020a). Contribution of travel and tourism to GDP as a share of GDP. Retrieved from https://knoema.com/atlas/topics/ Tourism/Travel-and-Tourism-Total-Contribution-to-GDP/Con tribution-of-travel-and-tourism-to-GDP-percent-of-GDP.

37. UNWTO. (2020). World tourism barometer. 18 (5). Retrieved from https://www.e-unwto.org/toc/wtobarometereng/18/5.

38. World Bank. (2018b). Investing in opportunity, ANNUAL REPORT 2018. Retrieved from http://documents1.worldbank. org/curated/en/630671538158537244/pdf/The-World-BankAnnual-Report-2018.pdf

39. Knoema. (2020b). The burden of COVID-19 on the tourism industry. Retrieved from https://knoema.com/clyulpb/the-burdenof-covid-19-on-the-tourism-industry

40. Fei, H., Qu, X., \& Kaye, C. (2020). COVID-19 and China's hotel industry: Impacts, a disaster management framework, and postpandemic agenda. International Journal of Hospitality Management, 90, 1-11. https://doi.org/10.1016/j.ijhm.2020.102636

41. Sun, D. (2020). Revitalization and future of the hospitality industry. Online. Retrieved from. Symposium conducted at the Rejuvenation Rebirth I 2020 China Cultural Tourism and Hospitality Industry Digital Summit. https://www.sohu.com/a/ 390913127_691563. 
42. World Bank. (2020c). International tourism, receipts (current US\$). 2020. Retrieved from https://data.worldbank.org/indicator/ ST.INT.RCPT.CD.

43. Lauren, U.C., Maksim, S. (2019). Travel and tourism at a tipping point. The Travel \& Tourism Competitiveness Report, 2019.
World Economic Forum. Retrieved from http://www3.weforum. org/docs/WEF_TTCR_2019.pdf.

Publisher's Note Springer Nature remains neutral with regard to jurisdictional claims in published maps and institutional affiliations. 